\title{
Synthesis and Formulation Development of Phenytoin by Inclusion Complexation
}

\author{
S. AGRAWAL*, SNEHAL GAIKWAD, RIYA PATEL, LEENA SHINDE AND A. DESHMUKH \\ Department of Pharmaceutics, SMBT College of Pharmacy, Nandi Hills, Dhamangaon, Nashik, Maharashtra 422401, India
}

Agrawal et al.: Synthesis and Formulation Development of Phenytoin

\begin{abstract}
Phenytoin is a classical anticonvulsant drug used in the treatment of epilepsy. It is a Biopharmaceutics classification system class II drug that has poor aqueous solubility, which affects dissolution rate. The main objective of this study was to enhance the dissolution rate of phenytoin and formulate the optimized chewable tablet. The phenytoin sodium was chemically synthesized and its solubility was enhanced with inclusion complexation by the kneading method using beta-cyclodextrin. This results in increased solubility of phenytoin sodium from 0.0150 to $0.0171 \mathrm{~g} / \mathrm{ml}$ and solubility was found to be directly proportional to concentration beta-cyclodextrin. Further, 22 factorial design was used to optimize phenytoin sodium chewable tablet with enhanced solubility. In vitro evaluations were done for all 12 formulations to find out the optimized formulation. We found the significant increase in the percentage of drug release, at the end of $2 \mathrm{~h}$, for formulation B6 (81.66\%) and C12 (92.76\%). Also, the pre-compressional and post-compressional properties of $\mathrm{B} 6$ and $\mathrm{C} 12$ formulations were found to be within the acceptable range of chewable tablets. In conclusion, the solubility of phenytoin sodium was enhanced and we successfully developed two (B6 and C12) optimized formulation of phenytoin sodium chewable tablet.
\end{abstract}

Key words: Epilepsy, solubility, phenytoin, biological availability

Epilepsy is one of the most common neurological diseases, with about 50 million patients globally ${ }^{[1]}$. Phenytoin is one of the potential candidates for epilepsy treatment, but it has low bioavailability due to lower aqueous solubility ${ }^{[2]}$. Fosphenytoin, a prodrug is widely used to overcome the low bioavailability problem of phenytoin. High cost, transient paraesthesia and pruritus are some of the disadvantages of fosphenytoin over phenytoin ${ }^{[3]}$.

Phenytoin sodium is a high-yielding chemically synthesized anticonvulsant drug, which is prescribed to be taken orally (phenytoin or phenytoin sodium) or by slow intravenous injection (phenytoin sodium). It stabilizes the excitable membranes of cardiac muscle and neuronal cells by decreasing the resting fluxes of sodium and inducing chemical depolarisations ${ }^{[4]}$. It is widely used to control tonic-clonic (grand mal) seizures, partial (focal) seizures and prophylactic seizures during neurosurgery or post-traumatic injury to the head ${ }^{[5]}$.

The oral dose of phenytoin sodium is 150 to $300 \mathrm{mg}$ daily, which can be increased gradually to $600 \mathrm{mg}$ according to the need of the patient. In status epilepsies, the maintenance dose is $100 \mathrm{mg} / 6 \mathrm{~h}$. The loading dose

*Address for correspondence

E-mail: shiv.p.10201@gmail.com

September-October 2021 of $10-15 \mathrm{mg} / \mathrm{kg}$ is given through slow Intravenous (IV) at the rate not exceeding $50 \mathrm{mg} / \mathrm{min}$. In children recommended initial dose is $5 \mathrm{mg} / \mathrm{kg}$ daily and a maintenance dose is $4-8 \mathrm{mg} / \mathrm{kg}$ daily in divided doses. Phenytoin sodium can also be used as an antiarrhythmic agent $^{[6]}$.

Phenytoin sodium can be administered through oral, IV or Intramuscular (IM) route. IM administration shows very slow absorption and is only appropriate to control prophylactic seizures during neurosurgery. It is usually prescribed daily to prevent convulsants, which makes self-administration difficult through the IV route ${ }^{[7]}$. Therefore, chewable tablets are mostly preferred over other routes of administration.

The direct compression method is one of the most effective techniques of tablet manufacturing. Direct compression is a simple and economical method for the

This is an open access article distributed under the terms of the Creative Commons Attribution-NonCommercial-ShareAlike 3.0 License, which allows others to remix, tweak, and build upon the work non-commercially, as long as the author is credited and the new creations are licensed under the identical terms

Accepted 25 September 2021

Revised 18 July 2021

Received 25 February 2020

Indian J Pharm Sci 2021;83(5):955-962 
manufacturing of tablets. It requires fewer processing steps than other techniques such as wet granulation and roller compaction. Some pharmaceutical active ingredients cannot be compressed directly into tablets due to lack of flow, cohesion properties and lubrication. Thus, such active ingredients are blended with other excipients that can be directly compressed ${ }^{[8]}$.

In this study, we chemically synthesized phenytoin sodium and enhanced its solubility with the inclusion complexation (kneading method) technique. Further, we aimed to formulate optimized phenytoin sodium chewable tablet with enhanced solubility, using $2^{2}$ factorial design. We also performed percompressional and post-compressional studies to identify the optimized formulation.

\section{MATERIALS AND METHODS}

All the chemicals used were supplied by SMBT College of Pharmacy, Dhamangaon, Nashik. The chemicals used were; Benzoin, acetic acid, sodium nitrate, copper sulphate, urea, Sodium Hydroxide $(\mathrm{NaOH})$, methanol, ethanol, chloroform, diethyl ether, Potassium Bromide $(\mathrm{KBr})$, Sodium Chloride $(\mathrm{NaCl})$, Hydrochloric Acid $(\mathrm{HCl})$, pyridine, cupric sulphate, Beta $(\beta)$-cyclodextrin, silicon dioxide, starch, magnesium stearate, mannitol, talc and sodium lauryl sulfate. All the chemicals used were of Laboratory Grade (LR).

\section{Synthesis:}

Synthesis of phenytoin: In the Round Bottom Flask (RBF), $4.3006 \mathrm{~g}$ benzoin, $12.5 \mathrm{ml}$ acetic acid and $2 \mathrm{~g}$ sodium nitrate were taken. The $2 \%$ copper sulfate was prepared separately and $2.5 \mathrm{ml}$ was added to RBF. The mixture in RBF was stirred in circumfluence for $1.5 \mathrm{~h}$. The mixture was cooled to $50-60^{\circ}$. Phenytoin was separated by placing the mixture in the ice water bath. Phenytoin was dried and recrystallized using methanol. Melting Point (MP) and Percentage (\%) yield of phenytoin was then calculated ${ }^{[9]}$.

Synthesis of phenytoin sodium: $2.1088 \mathrm{~g}$ phenytoin and $0.6103 \mathrm{~g}$ urea were added to a $50 \mathrm{ml}$ flask, containing $5 \mathrm{ml}$ water maintained at $98^{\circ}$. Then, $6 \mathrm{ml} 30 \% \mathrm{NaOH}$ was added drop wise into the reactor in circumfluence for $1 \mathrm{~h}$. The mixture was discolored, by adding $10 \mathrm{ml}$ of water. The mixture was then filtered and the filtrate was adjusted to $\mathrm{pH} \mathrm{5-6}$ at $45^{\circ}$. The precipitate was washed with water to obtain 5,5-diphenylhydantoin (diphenylhydantoin). Diphenylhydantoin was adjusted to the $\mathrm{pH} 11-11.5$ by using $30 \% \mathrm{NaOH}$, which was then discolored by heating at $70-80^{\circ}$ for $0.5 \mathrm{~h}$. The solution was filtered and the residue was dried to obtain the phenytoin sodium (product) ${ }^{[9]}$. MP and percentage yield of phenytoin sodium was then calculated.

\section{Drug evaluation:}

Organoleptic properties: Visual colour and odour were found out.

Solubility: The amount of solvent required for complete saturation of $1 \mathrm{~g}$ of phenytoin sodium was found out. Solubility of phenytoin sodium in water, ethanol, chloroform and diethyl ether was calculated ${ }^{[10]}$.

Melting point: The MP was determined using digital melting point apparatus (model S-972). One end of the capillary tube was sealed and dried phenytoin sodium was filled by jabbing the open end of the tube. The tube was inverted and gently tapped on the benchtop to cause the solid to fall to the closed end and was filled up to 2-3 $\mathrm{mm}$ of height. The tube was placed into the melting point apparatus. Once the temperature of $20^{\circ}$ below the expected melting point was reached, the temperature was further increased at the rate of not more than $1^{\circ}$ every $30 \mathrm{~s}$. The melting point range was recorded from the first visible drop of liquid to a completely melted solid ${ }^{[10]}$.

Infrared Spectroscopy (IR): The IR of the synthesized drug was found out using Jasco Fourier-Transform (FT)/IR instrument (model 4100). The sample was prepared by using the $\mathrm{KBr}$ pellet technique. Dried $\mathrm{KBr}$ powder was used in a ratio of 100 times the weight of pure phenytoin sodium. The phenytoin sodium and $\mathrm{KBr}$ mixture were pressed in a die at 10000 to 15000 pounds. The disk was then held in the path of the IR beam of the instrument for spectroscopic examination. The resulting spectra showed bands at $3450 \mathrm{~cm}^{-1}$ and $1640 \mathrm{~cm}^{-1}$ due to absorbed moisture. Carbon dioxide and water absorption were removed manually ${ }^{[11]}$. The IR spectrum was compared with the reference spectrum of phenytoin published in a book by Philip et al. ${ }^{[12]}$.

Elemental analysis: The sodium concentration in the synthesized drug was detected using flame photometry (model SLiSCO) at $589 \mathrm{~nm}$. $\mathrm{NaCl}$ standard solution was used to prepare series of dilutions, having a concentration of $5,10,25,50,75,100 \mathrm{mg} / \mathrm{ml}$. The calibration curve was drawn. The sample solution was prepared and the emission was recorded to find out the concentration of sodium in a sample ${ }^{[13-16]}$.

Ultraviolet (UV): A Jasco double beam spectrophotometer (model V-730) was used. Standard 
stock solution $(0.1 \mathrm{mg} / \mathrm{ml})$ of phenytoin sodium in ethanol was prepared. A dilutions series of concentration $2,4,6,8,10,12$ and $14 \mu \mathrm{g} / \mathrm{ml}$ was prepared using standard stock solution and ethanol. The baseline was obtained using $14 \mu \mathrm{g} / \mathrm{ml}$ dilution at 200-250 $\mathrm{nm}$. The maximum absorbance was found out using ethanol as blank. The absorbances of serial dilutions (each analysis in triplicate) were calculated using Beer-Lambert's law. The standard curve of concentration vs. absorbance was plotted to find linearity. The method was validated using Limit of Detection (LOD), Limit of Quantitation (LOQ), Standard Deviation (SD) and Relative standard Deviation (RSD).

Chemical analysis: $0.25 \mathrm{~g}$ of the drug was dissolved in $5 \mathrm{ml}$ of water and acidified with dilute $\mathrm{HCl}$. It should produce a white precipitate; $0.1 \mathrm{~g}$ of the drug was dissolved in $10 \mathrm{ml}$ of a $10 \% \mathrm{w} / \mathrm{v}$ solution of pyridine, $1 \mathrm{ml}$ of cupric sulphate with pyridine solution was added and allowed to stand for $10 \mathrm{~min}$. The blue precipitate must be produced ${ }^{[6]}$.

\section{Solubility enhancement:}

Solubility is defined in quantitative terms as the concentration of the solute in a saturated solution at a certain temperature. In qualitative terms, it may be defined as the spontaneous interaction of two or more substances to form a homogeneous moleculardispersion. Drug solubility is the maximum concentration of the drug solute dissolved in the solvent under the specific condition of temperature, $\mathrm{pH}$ and pressure ${ }^{[18]}$.

Phenytoin sodium has low solubility and high permeability. It belongs to a class II drug in Biopharmaceutics Classification System (BCS ${ }^{[19]}$. Its solubility was enhanced by the phenomenon of inclusion complexation by using the kneading $\operatorname{method}^{[20,21]}$. The kneaded mass of $\beta$-cyclodextrin and the drug was prepared using a sufficient amount of water. The kneaded mass was dried at $45^{\circ}$ and pulverized $^{[22,23]}$. The $\beta$-cyclodextrin was used in three different concentrations to observe its effect on solubility. Table 1 represents the combination A, B and $\mathrm{C}$ with the corresponding proportions of phenytoin sodium and $\beta$-cyclodextrin used for kneading.

\section{Evaluation of enhanced solubility:}

The Shake-flask method was used to determine the equilibrium solubility at a given $\mathrm{pH}$ and temperature. Phenytoin sodium was added in surplus to ethanol, which was then shaken at a predetermined time interval for $24 \mathrm{~h}$. The undissolved material represents the saturated solution. The saturated solution was filtered and UV analysis of filtrate was performed to determine the enhanced solubility (concentration) ${ }^{[24,25]}$.

\section{Formulation of chewable tablet:}

The solubility enhanced drug (mixture of phenytoin sodium and $\beta$-cyclodextrin by kneading method) was used to formulate a chewable tablet. The $2^{2}$ factorial design was applied for two factors i.e. silicon dioxide and starch (Table 2 and Table 3). The excipients used were silicon dioxide, starch, magnesium stearate, talc, mannitol and solubility enhanced drug along with $\beta$-cyclodextrin. One high and one low level was set up for silicon dioxide and starch. For each solubility enhanced drug (combination A, B, C) $2^{2}$ factorial design was applied. Total 12 formulations were obtained (4 for each $\mathrm{A}, \mathrm{B}$ and $\mathrm{C}$ combination), which were labelled as $\mathrm{A} 1$ to $\mathrm{A} 4$ for $\mathrm{A}, \mathrm{B} 5$ to $\mathrm{B} 8$ for $\mathrm{B}, \mathrm{C} 9$ to $\mathrm{C} 12$ for

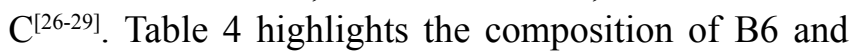
C12 formulations.

Five excipients were selected based on their organic properties, particle size, density, compressibility, flow ability, mode of compression and water solubility to optimize powder compatibility, blend uniformity, tablet appearance, tablet weight, tablet hardness, tablet

\begin{tabular}{lccc}
$\begin{array}{l}\text { TABLE 1: } \\
\text { PROPORTIONS }\end{array}$ & AND & \multicolumn{2}{c}{$\boldsymbol{\beta}$-CYCLODEXTRIN } \\
\hline Ingredient & $\begin{array}{c}\text { A } \\
(\mathbf{m g})\end{array}$ & $\begin{array}{c}\text { B } \\
(\mathbf{m g})\end{array}$ & $\begin{array}{c}\mathrm{C} \\
(\mathbf{m g})\end{array}$ \\
\hline Drug & 100 & 100 & 100 \\
B-Cyclodextrin & 300 & 400 & 500 \\
\hline
\end{tabular}

TABLE 2: LEVELS OF FACTOR

\begin{tabular}{lccc}
\hline S. No. & Factor & Low level & High level \\
\hline 1 & Silicon dioxide (A) & - & + \\
2 & Starch (B) & - & + \\
\hline
\end{tabular}

TABLE 3: TWO-LEVEL 2 FACTOR-FULL FACTORIAL EXPERIMENT DESIGN PATTERN

\begin{tabular}{lccc}
\hline \multirow{2}{*}{ Formulations } & \multirow{2}{*}{ Combination } & \multicolumn{2}{c}{ Factor } \\
\cline { 3 - 4 } & & A & B \\
\hline A1 & 1 & - & - \\
A2 & $\mathrm{A}$ & + & - \\
A3 & $\mathrm{B}$ & - & + \\
A4 & $\mathrm{AB}$ & + & + \\
B5 & 1 & - & - \\
B6 & $\mathrm{A}$ & + & - \\
B7 & $\mathrm{B}$ & - & + \\
B8 & $\mathrm{AB}$ & + & + \\
C9 & 1 & - & - \\
C10 & $\mathrm{A}$ & + & - \\
C11 & $\mathrm{B}$ & - & + \\
C12 & $\mathrm{AB}$ & + & + \\
\hline
\end{tabular}


friability and tablet disintegration ${ }^{[30]}$. As previously reported in the literature, the excipients had no drugexcipients interactions ${ }^{[31-33]}$. Drug and excipients were weighted accurately, passed through sieve no. 80 and were mixed completely for $5 \mathrm{~min}$. The chewable tablets were prepared by the direct compression method. The 8 stage mini rotary tablet press was used for tablet compression. All 12 batches were performed similarly.

\section{Evaluation of tablet:}

Pre-compressional studies of drug and excipients: The pre-compressional studies were performed before compression, for the potential development of a drug. The flow properties were calculated to obtain flow ability. The flow properties evaluated were the angle of repose, Carr's index, bulk density and tapped density.

Angle of repose $(\theta)=\tan ^{-1} \mathrm{~h} / \mathrm{r}$

Bulk density $(\rho b)=M / \mathrm{Vb}$ (where, $\mathrm{M}$ is the mass of the sample, $\mathrm{Vb}$ bulk volume)

Tapped density $(\rho t)=$ Weight of powder blend/Minimum volume occupied by cylinder

Carr's index=Tapped density-Bulk density $\times 100$ / Tapped density ${ }^{[34]}$.

\section{Post-compressional evaluation:}

Thickness: The tablet thickness was calculated by vernier callipers. Tablet was placed in between two jaws vertically and thickness was measured. 12 tablets were used for this test and thickness was expressed in $\mathrm{mm}^{[34]}$.

Hardness: Hardness is a diametric tablet crushing strength. The tablet hardness was determined by the Monsanto hardness tester. The tablet was placed lengthwise between the upper and lower plunger and force was applied until the tablet fractures, to give the hardness of the tablet in $\mathrm{kg} / \mathrm{cm}^{2[34]}$.

Weight variation test: From each formulation, the weight of 20 tablets was recorded. The average weight of an individual tablet was then calculated. The weight of the individual tablet was recorded. The percentage weight deviation (variation) was calculated using the formula:

$\%$ weight deviation $($ variation $)=(\mathrm{IW}-\mathrm{AW}) / \mathrm{AW} \times 100$

Where, IW is Individual Weight; AW is Average Weight . The percentage weight deviation should be present within the allowed percent deviation as per Indian Pharmacopoeia(IP)/United States Pharmacopeia(USP).

Table 5 represents the percentage weight deviation allowed according to IP/British Pharmacopoeia (BP)/

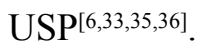

Friability: It is a method to determine the physical strength of uncoated tablets upon exposure to mechanical shock and attrition. The weight of 15 tablets was recorded. All tablets were placed in the friability apparatus, revolving at 24-25 rpm for $4 \mathrm{~min}$ (100 times). After 100 revolutions the tablets were dedusted and reweighted ${ }^{[37]}$. The percentage friability is determined from the weight loss using the formula:

$\%$ Friability $=\mathrm{W}_{\mathrm{i}}-\mathrm{W}_{\mathrm{f}} / \mathrm{W}_{\mathrm{i}} \times 100$ (where, $\mathrm{W}_{\mathrm{i}}$ is weight before a test, $\mathrm{W}_{\mathrm{f}}$ is weight after a test)

Disintegration test: It is the time taken by the tablet to disintegrate, which was measured using the disintegration test apparatus as described in the USP/ National Formulary (NF). One tablet was placed in each of the 6 tubes with $10 \mathrm{~nm}$ mesh at the closed end. The basket rack was positioned in a 11 beaker of water at $37^{\circ}$. The time taken for complete disintegration was noted $^{[38]}$.

\section{Dissolution studies:}

The in vitro drug release studies (dissolution studies) were performed using USP dissolution apparatus Type II (paddle apparatus), with $900 \mathrm{ml}$ of $0.05 \mathrm{M}$ Tris buffer as the dissolution medium. The dissolution medium was maintained at $37^{\circ}$, with a paddle rotation speed of $100 \mathrm{rpm}$. Each sampling was done by withdrawing $5 \mathrm{ml}$ of a sample at a 10 min time interval for about $2 \mathrm{~h}$. On each withdrawal of sample, $5 \mathrm{ml}$ of buffer was re-added. The collected samples were suitably diluted. The absorbance of the solutions was determined at $\lambda_{\max }$ of $214 \mathrm{~nm}$ in a UV visible spectrophotometer, using buffer solution as a blank ${ }^{[36,39]}$.

TABLE 4: COMPOSITIONS OF FORMULATIONS B6 AND C12

\begin{tabular}{lcc}
\hline Ingredients & B6 (\%) & C12 (\%) \\
\hline Silicon Dioxide & 5 & 5 \\
Starch & 15 & 25 \\
Combination by kneading & 14 & 14 \\
Magnesium Stearate & 1.5 & 1.5 \\
Talc & 4 & 4 \\
Mannitol & q.s. & q.s. \\
\hline
\end{tabular}

TABLE 5: PERCENTAGE WEIGHT DEVIATION ALLOWED

\begin{tabular}{lcc}
\hline IP/BP & Limit & USP \\
\hline $80 \mathrm{mg}$ or less & $10 \%$ & $130 \mathrm{mg}$ or less \\
$80 \mathrm{mg}$ to $250 \mathrm{mg}$ & $7.5 \%$ & $130 \mathrm{mg}$ to $324 \mathrm{mg}$ \\
$250 \mathrm{mg}$ or more & $5 \%$ & More than $324 \mathrm{mg}$ \\
\hline
\end{tabular}




\section{RESULTS AND DISCUSSION}

The percentage yield and MP of phenytoin was found to be $63 \%$ and $280-282^{\circ}$, respectively. The percentage yield and MP of phenytoin sodium was found to be $56 \%$ and $290-292^{\circ}$, respectively. The percentage yield was observed to be reduced after recrystallization. White, odourless powder of phenytoin sodium was obtained. Phenytoin sodium was soluble in water $(1 \mathrm{~g} / 61 \mathrm{ml})$ and ethanol $(1 \mathrm{~g} / 12.3 \mathrm{ml})$ and insoluble in chloroform and diethyl ether. Yellow color of flame was observed in flame photometry, which shows the presence of sodium in the sample ${ }^{[40]}$. The concentration of sodium was found out to be $11 \%$. Outcomes of these primary identification test match with the properties of phenytoin sodium.

In the IR spectrums of the synthesized drug (fig. 1), $3271.27 \mathrm{~cm}^{-1}$ and $3207.62 \mathrm{~cm}^{-1}$ were assigned to the stretching vibration of secondary amines. $3070.68 \mathrm{~cm}^{-1}$ was assigned to stretching vibration of $=\mathrm{C}-\mathrm{H}$ on the aromatic ring. $1722.43 \mathrm{~cm}^{-1}$ was assigned to stretching vibration of $\mathrm{C}=\mathrm{O}$. The $1494.83 \mathrm{~cm}^{-1}$ was assigned to the skeleton vibration of the aromatic ring. The IR spectrum of the drug matches the reference spectrum of phenytoin sodium.

The performed dilutions were scanned at 200-400 nm. $\lambda_{\max }$ for the highest concentration was found out to be $207 \mathrm{~nm}$ using ethanol as blank. The observed $\lambda_{\max }$ matches the $\lambda_{\text {max }}$ of phenytoin sodium ${ }^{[6,36]}$. Except for peaks at $207 \mathrm{~nm}$, no other peaks were seen in the UV spectrum, which represents the sample had no impurity. Table 6 represents the absorbance and validation results. Table 7 shows the summary of validation parameters for the proposed UV method. Fig. 2 represents the standard curve of phenytoin sodium in ethanol. The calibration curve and $\mathrm{R}^{2}$ show the linearity. Low $\%$ RSD values represent that the method is precise. The microgram level of LOQ and LOD indicates the method to be sensitive ${ }^{[4]}$. Therefore the proposed UV analysis method is validated.

White precipitate was observed on acidification of aqueous solution of phenytoin sodium; the blue precipitate was observed after $10 \mathrm{~min}$ of mixing the cupric sulphate with a pyridine solution of phenytoin sodium. Chemical analysis indicated that the synthesized drug is phenytoin sodium. Therefore, from all the above analysis it can be concluded that the synthesized drug is phenytoin sodium.

Table 8 shows the different compositions of kneaded mass and their solubility. The results show enhanced solubility of phenytoin sodium. The highest solubility was found for $500 \mathrm{mg} \beta$-cyclodextrin with $100 \mathrm{mg}$ of phenytoin sodium. It is observed that the solubility increases with the increase in the concentration of $\beta$-cyclodextrin.

The flow properties are given in Table 9. Except for A2 and B5, all other formulations have an angle of repose

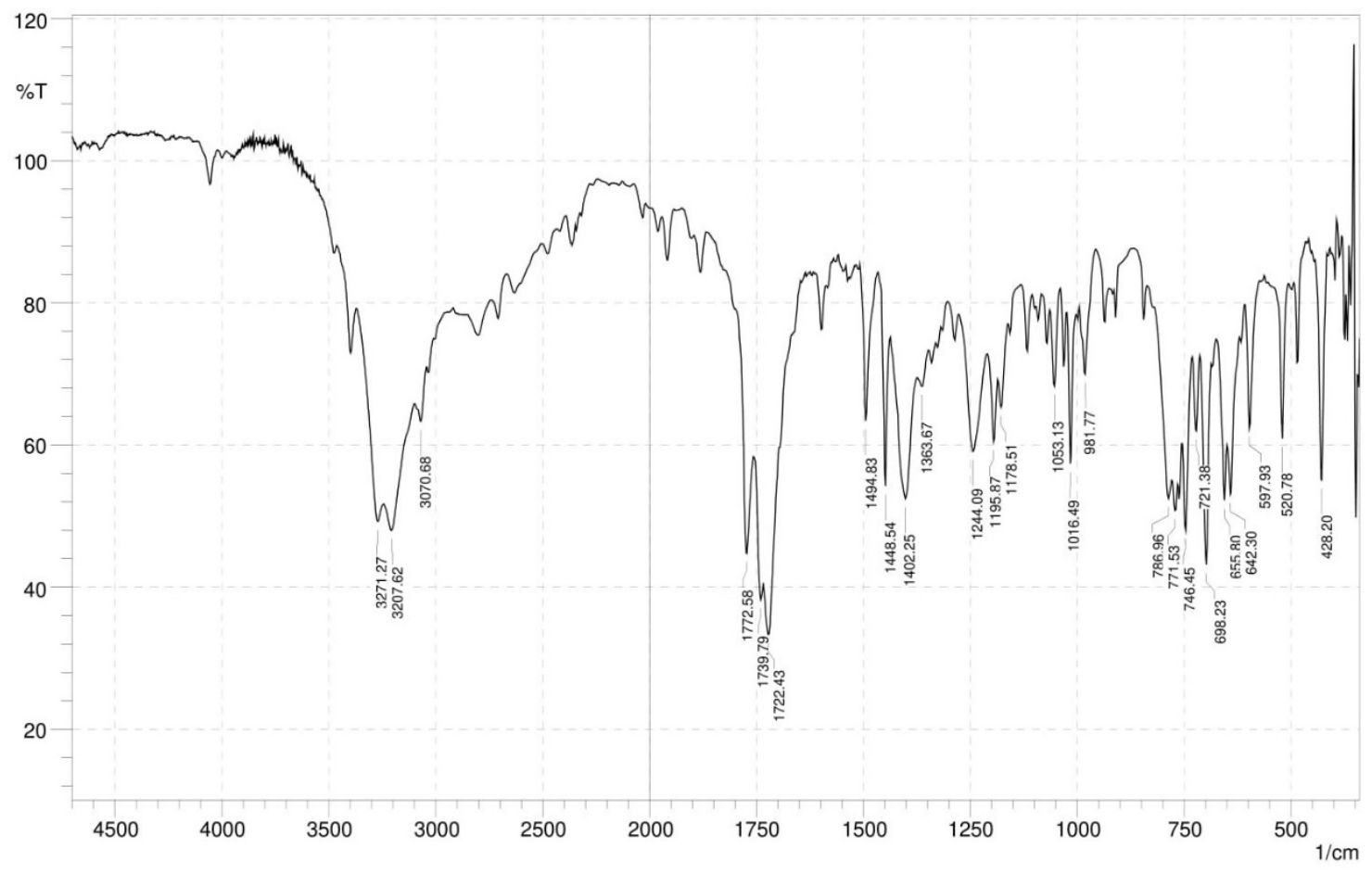

Fig. 1: IR spectrum of synthesized phenytoin sodium 
TABLE 6: UV ABSORBANCE AND VALIDATION

\begin{tabular}{lcccc}
\hline $\begin{array}{l}\text { Concentration } \\
(\mu \mathrm{g} / \mathrm{ml})\end{array}$ & Absorbance & SD & RSD & $\begin{array}{c}\% \\
\text { Recovery }\end{array}$ \\
\hline 2 & 0.215 & 0.006807 & 3.165981 & 100.233 \\
4 & 0.492 & 0.012530 & 2.546741 & 100.343 \\
6 & 0.735 & 0.013577 & 1.846366 & 100.136 \\
8 & 0.983 & 0.011590 & 1.178667 & 100.128 \\
10 & 1.23 & 0.018148 & 1.475410 & 100.108 \\
\hline
\end{tabular}

TABLE 7: VALIDATION PARAMETERS

\begin{tabular}{lc}
\hline Parameters (units) & Result \\
\hline Absorption maxima $(\mathrm{nm})$ & 207 \\
Linearity range $(\mu \mathrm{g} / \mathrm{ml})$ & $2-10$ \\
Standard regression equation & $\mathrm{y}=0.1261 \mathrm{x}-0.0253$ \\
Regression coefficient $\left(\mathrm{R}^{2}\right)$ & $\mathrm{R}^{2}=0.9994$ \\
$\%$ Accuracy & 100.1896 \\
Precision & $1.475-3.165$ \\
LOD $(\mu \mathrm{g} / \mathrm{ml})$ & 0.32791 \\
LOQ $(\mu \mathrm{g} / \mathrm{ml})$ & 0.99368 \\
\hline
\end{tabular}

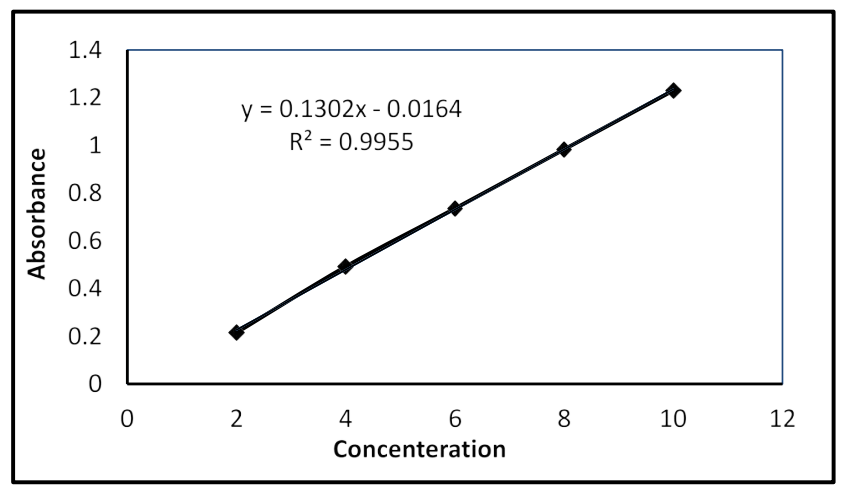

Fig. 2: Standard curve of phenytoin sodium in ethanol

TABLE 8: SOLUBILITY ENHANCEMENT RESULTS

\begin{tabular}{lc}
\hline Combination & $\begin{array}{c}\text { Concentration } \\
(\mathrm{g} / \mathrm{ml})\end{array}$ \\
\hline Phenytoin sodium & 0.0150 \\
$\mathrm{~A}$ & 0.0159 \\
$\mathrm{~B}$ & 0.0163 \\
$\mathrm{C}$ & 0.0171 \\
\hline
\end{tabular}

TABLE 9: PRE-COMPRESSION PARAMETER less than $35^{\circ}$, which indicates good flow ability. The highest bulk density was found to be $0.76 \pm 0.01 \mathrm{~g} / \mathrm{ml}$ for A2 and the lowest was found out to be $0.33 \pm 0.01 \mathrm{~g} / \mathrm{ml}$ for B7. Similarly, highest and lowest tapped densities were $0.92 \pm 0.01 \mathrm{mg} / \mathrm{ml}$ (A2) and $0.52 \pm 0.01 \mathrm{mg} / \mathrm{ml}$ (C12). Carr's index value indicates formulation B6, C9 and $\mathrm{C} 10$ has excellent flow ability, formulation A2, A3 and $\mathrm{C} 12$ has good flow ability and formulation A1, B5 and $\mathrm{C} 11$ have very poor flow property ${ }^{[6]}$.

The tablets were compressed by the direct compression technique. The hardness for the conventional tab is between $4-10 \mathrm{~kg} / \mathrm{cm}^{2}$ but for chewable tablet, the hardness should be up to $3 \mathrm{~kg} / \mathrm{cm}^{2[42]}$. Hardness (Table 10) for all formulation except for A4, B8, C9 and $\mathrm{C} 11$ is less than $3 \mathrm{~kg} / \mathrm{cm}^{2}$.

Based on our result, the average thickness of tablets is $4.058 \mathrm{~mm}$, as the thickness obtained for every 12 tablets lies within the range of $3.80 \mathrm{~mm}$ to $4.20 \mathrm{~mm}$ (Table 10). According to the average weight of 20 tablets, for each A1-C12 formulation percentage weight variation allowed was $5 \%$ and it was reported that the batches of all the formulation passed the weight variation test (Table 10). Thus, all the tablets within each formulation have a uniformity ${ }^{[43]}$. The percentage friability was below $1 \%$ and no tablet was broken (Table 10). Thus, all the formulation passed the percentage friability test, which indicates all the formulations are resistant to friability.

In dissolution studies, the maximum percentage of drug release $(2 \mathrm{~h}$ ) was recorded to be $92.76 \%$ and $81.66 \%$ for C12 and B6 formulations, respectively (Table 11). For most of the other formulation, the percentage of drug release was found to be less than $60 \%$, which were then discarded. Fig. 3 represents the graph percentage of drug release against time for $\mathrm{C} 12$ and $\mathrm{B} 6$ formulations.

The pre-compressional and post-compressional studies show that the formulations $\mathrm{C} 12$ and B6 are optimal.

\begin{tabular}{lcccc}
\hline Formulations & Bulk density $(\mathrm{g} / \mathrm{ml})$ & Tapped density $(\mathrm{g} / \mathrm{ml})$ & Angle of repose $(\theta)$ & Carr's index \\
\hline A1 & $0.48 \pm 0.017$ & $0.86 \pm 0.01$ & $25.3 \pm 0.264$ & $44.19 \pm 1.477$ \\
A2 & $0.76 \pm 0.01$ & $0.92 \pm 0.01$ & $38.7 \pm 0.1$ & $17.39 \pm 0.189$ \\
A3 & $0.51 \pm 0.01$ & $0.62 \pm 0.017$ & $33.8 \pm 0.1$ & $17.72 \pm 1.207$ \\
A4 & $0.44 \pm 0.02$ & $0.59 \pm 0.026$ & $22.7 \pm 0.2$ & $25.42 \pm 1.139$ \\
B5 & $0.59 \pm 0.01$ & $0.85 \pm 0.01$ & $36.4 \pm 0.1$ & $30.57 \pm 1.993$ \\
B6 & $0.47 \pm 0.02$ & $0.53 \pm 0.01$ & $30.5 \pm 0.2$ & $11.31 \pm 1.775$ \\
B7 & $0.33 \pm 0.01$ & $0.44 \pm 0.01$ & $33.3 \pm 0.1$ & $24.95 \pm 3.415$ \\
B8 & $0.42 \pm 0.01$ & $0.53 \pm 0.02$ & $32.6 \pm 0.26$ & $20.63 \pm 4.885$ \\
C9 & $0.73 \pm 0.01$ & $0.82 \pm 0.01$ & $25.6 \pm 0.132$ & $10.97 \pm 0.133$ \\
C10 & $0.62 \pm 0.02$ & $0.69 \pm 0.01$ & $24.1 \pm 0.229$ & $10.14 \pm 2.512$ \\
C11 & $0.46 \pm 0.01$ & $0.76 \pm 0.01$ & $33.2 \pm 0.1$ & $39.45 \pm 2.112$ \\
C12 & $0.43 \pm 0.01$ & $0.52 \pm 0.01$ & $25.7 \pm 0.132$ & $17.31 \pm 0.332$ \\
\hline
\end{tabular}


www.ijpsonline.com

TABLE 10: POST-COMPRESSION PARAMETER

\begin{tabular}{|c|c|c|c|c|c|}
\hline Formulations & Hardness $\left(\mathrm{kg} / \mathrm{cm}^{2}\right)$ & $\begin{array}{c}\text { Thickness } \\
(\mathrm{mm})\end{array}$ & $\begin{array}{l}\% \text { Weight } \\
\text { variation }\end{array}$ & \% Friability & $\begin{array}{c}\text { Disintegration } \\
\text { time (min) }\end{array}$ \\
\hline $\mathrm{A} 1$ & $2.30 \pm 0.026$ & $4 \pm 0.073$ & $4.1 \pm 0.021$ & $0.01 \pm 0.001$ & $7.1 \pm 0.164$ \\
\hline $\mathrm{A} 2$ & $2.92 \pm 0.095$ & $4.2 \pm 0.056$ & $3.8 \pm 0.021$ & $0.03 \pm 0.003$ & $7.6 \pm 0.302$ \\
\hline A3 & $2.5 \pm 0.081$ & $3.9 \pm 0.052$ & $4.3 \pm 0.021$ & $0.05 \pm 0.001$ & $6.8 \pm 0.26$ \\
\hline A4 & $3.3 \pm 0.078$ & $3.5 \pm 0.047$ & $4.5 \pm 0.022$ & $0.01 \pm 0.003$ & $8.4 \pm 0.242$ \\
\hline B5 & $2.1 \pm 0.127$ & $4.0 \pm 0.052$ & $3.2 \pm 0.021$ & $0.2 \pm 0.03$ & $8.1 \pm 0.289$ \\
\hline B6 & $2.23 \pm 0.06$ & $3.8 \pm 0.047$ & $4.3 \pm 0.016$ & $0.4 \pm 0.01$ & $8.6 \pm 0.235$ \\
\hline B7 & $2.76 \pm 0.087$ & $4.2 \pm 0.067$ & $4.0 \pm 0.026$ & $0.1 \pm 0.026$ & $7.8 \pm 0.609$ \\
\hline B8 & $3.98 \pm 0.072$ & $4.8 \pm 0.1$ & $3.8 \pm 0.023$ & $0.3 \pm 0.026$ & $8.4 \pm 0.401$ \\
\hline $\mathrm{C} 9$ & $3.39 \pm 0.079$ & $3.9 \pm 0.056$ & $2.9 \pm 0.022$ & $0.6 \pm 0.01$ & $7.5 \pm 0.42$ \\
\hline C10 & $2.2 \pm 0.043$ & $4.5 \pm 0.036$ & $4.1 \pm 0.024$ & $0.5 \pm 0.036$ & $9.0 \pm 0.25$ \\
\hline C11 & $3.20 \pm 0.062$ & $3.8 \pm 0.082$ & $4.7 \pm 0.027$ & $0.7 \pm 0.01$ & $8.1 \pm 0.271$ \\
\hline $\mathrm{C} 12$ & $2.34 \pm 0.06$ & $4.1 \pm 0.042$ & $3.5 \pm 0.016$ & $0.4 \pm 0.017$ & $9.2 \pm 0.151$ \\
\hline
\end{tabular}

TABLE 11: DISSOLUTION TESTING (\% DRUG RELEASE)

\begin{tabular}{lcc}
\hline Sampling time $(\mathrm{min})$ & B6 (\%) & C12 (\%) \\
\hline 10 & 6.21 & 5.71 \\
20 & 11.3 & 12.46 \\
30 & 17.6 & 19.16 \\
40 & 22.53 & 26.45 \\
50 & 29.26 & 33.32 \\
60 & 35.35 & 39.43 \\
70 & 41.83 & 46.07 \\
80 & 46.2 & 54.8 \\
90 & 55.3 & 67.2 \\
100 & 68.35 & 75.03 \\
110 & 75.12 & 82.57 \\
120 & 81.66 & 92.76 \\
\hline
\end{tabular}

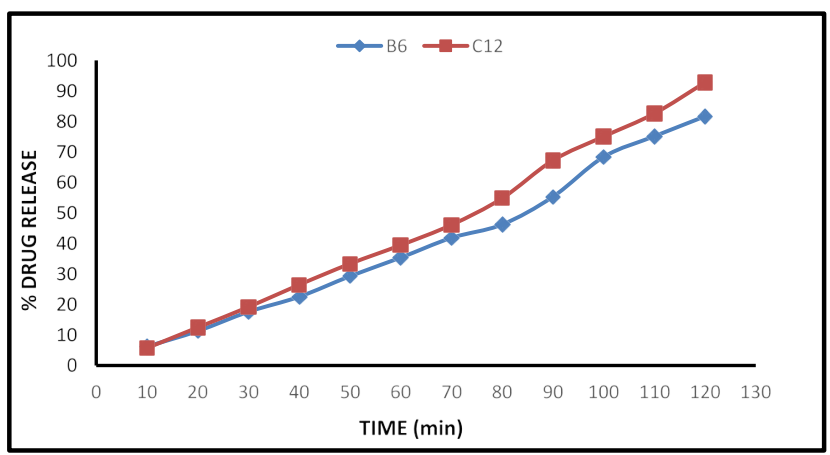

Fig. 3: Percentage drug release of $\mathrm{B} 6$ and $\mathrm{C} 12$ formulation

In conclusion, the solubility of phenytoin sodium was enhanced and an optimized chewable tablet formulation was developed.

\section{Acknowledgements:}

The authors thank Dr. A. S. Dhake, Dr. A. R. Surana and Mr. P.R. Dighe for their necessary guidance for the present research work.

\section{Conflict of interests:}

The authors declared no conflicts of interest.

\section{REFERENCES}

1. Beghi E, Giussani G, Nichols E, Abd-Allah F, Abdela J, Abdelalim A, et al. Global, regional and national burden of epilepsy, 1990-2016: a systematic analysis for the Global Burden of Disease Study 2016. Lancet Neurol 2019;18(4):35775.

2. Chiang PC, Wong H. Incorporation of physiologically based pharmacokinetic modeling in the evaluation of solubility requirements for the salt selection process: a case study using phenytoin. AAPS 2013;15(4):1109-18.

3. Schachter SC. Anticonvulsant Agents: Phenytoin and Fosphenytoin. In: Riederer P, Laux G, et al. editors. NeuroPsychopharmacotherapy. Cham: Springer International Publishing; 2020. p. 1-6.

4. Hesselink JM. Phenytoin: a step by step insight into its multiple mechanisms of action-80 years of mechanistic studies in neuropharmacology. J Neurol 2017;264(9):2043-7.

5. Patocka J, Wu Q, Nepovimova E, Kuca K. Phenytoin-An antiseizure drug: Overview of its chemistry, pharmacology and toxicology. Food Chem Toxicol 2020;142:111393.

6. Indian Pharmacopoeia. $8^{\text {th }}$ ed. Controller of Publication, Govt. of India, Ministry of Health and Family Welfare, New Delhi; 2018. p. 2917-8.

7. Agarwal P, Kumar N, Chandra R, Gupta G, Antony AR, Garg $\mathrm{N}$. Randomized study of intravenous valproate and phenytoin in status epilepticus. Seizure 2007;16(6):527-32.

8. Parashar B, Chauhan A, Prashar D, Chandel A, Kumar H, Purohit R. Formulation and evaluation aspects of tablets-An overview. Am J PharmTech Res 2012;2(1):2249-3387.

9. Du TT, Li JF, Min LJ. Green Synthesis of Phenytoin Sodium. Adv Mat Res 2012;518-523:3917-20.

10. Mohrig JR, Hammond CN, Schatz PF. Techniques in organic chemistry. $3^{\text {rd }}$ ed. New York: Macmillan; 2009. p. 174-82.

11. Skoog DA, Holler FJ, Crouch SR. Principles of instrumental analysis. $6^{\text {th }}$ ed. New Delhi: Cengage learning; 2014. p. 477504.

12. Philip J, Holcomb IJ, Fusari SA. Phenytoin. In: Florey K, editor. Analytical Profiles of Drug Substances. Vol. 13: 
Academic Press; 1984. p. 420.

13. Kar A. Pharmaceutical drug analysis. New Age International; 2005.

14. Banerjee P, Prasad B. Determination of concentration of total sodium and potassium in surface and ground water using a flame photometer. Appl Water Sci 2020;10(5):1-7.

15. Harris DC. Quantitative chemical analysis. $6^{\text {th }}$ ed. New York: W.H. Freeman and Company; 2010.

16. Heineman RB, Janice M, Sawyer DT. Chemistry experiments for instrumental methods. $1^{\text {st }}$ ed. New York: John Wiley \& Sons; 1984.

17. Mantri MA, Shanmukhappa S. UV spectrophotometric estimation of phenytoin sodium in pure and pharmaceutical formulations. Asian J Chem 2010;22(3):2447-9.

18. Kumar S, Singh P. Various techniques for solubility enhancement: An overview. Pharm Innov 2016;5(1):23-8.

19. Lindenberg M, Kopp S, Dressman JB. Classification of orally administered drugs on the World Health Organization Model list of Essential Medicines according to the biopharmaceutics classification system. Eur J Pharm Biopharm 2004;58(2):26578.

20. dos Santos Lima B, de Alcântara Campos C, da Silva Santos ACR, Santos VCN, Trindade GdGG, Shanmugam S, et al. Development of morin/hydroxypropyl- $\beta$-cyclodextrin inclusion complex: Enhancement of bioavailability, antihyperalgesic and anti-inflammatory effects. Food Chem Toxicol 2019;126:15-24.

21. Patel HM, Suhagia BN, Shah SA, Rathod IS, Parmar VK. Preparation and characterization of etoricoxib $\beta$-cyclodextrin complexes prepared by the kneading method. Acta Pharm 2007;57(3):351-59.

22. Devi NKD, Rani AP, Javed M, Kumar K, Kaushik J, Sowjanya V. Cyclodextrins in pharmacy-an overview. Pharmacophore 2010;1(3):155-65.

23. Choi HG, Lee BJ, Han JH, Lee MK, Park KM, Yong CS, et al. Terfenadine- $\beta$-cyclodextrin inclusion complex with antihistaminic activity enhancement. Drug Dev Ind Pharm 2001;27(8):857-62.

24. Larsson J. Methods for measurement of solubility and dissolution rate of sparingly soluble drugs: Lunds Unversitey; 2009.

25. Baka E, Comer JE, Takács-Novák K. Study of equilibrium solubility measurement by saturation shake-flask method using hydrohlorothiazide as model compound. J Pharm Biomed Anal 2008;46(2):335-41.

26. Rowe RC, Sheskey P, Quinn M. Handbook of pharmaceutical excipients. $6^{\text {th }}$ ed. London: Libros Digitales-Pharmaceutical Press; 2009.

27. Hanrahan G, Lu K. Application of factorial and response surface methodology in modern experimental design and optimization. Crit Rev Anal Chem 2006;36(3-4):141-51.
28. Hani U, Krishna G, Shivakumar HG. Design and optimization of clotrimazole-hydroxypropyl- $\beta$-cyclodextrin bioadhesive vaginal tablets using Anacardium occidentale gum by $3^{2}$ factorial design. RSC Adv 2015;5(45):35391-404.

29. Mee R. A comprehensive guide to factorial two-level experimentation. New York: Springer Science \& Business Media; 2009. p. 3-6.

30. Maltais M, Vargas R, DiPaolo T. Development of a new formulation for direct compression of a natural product. $\mathrm{J}$ Pharm Technol Drug Res 2015;4(2).

31. Rahman Z, Dharani S, Ali SFB, Nutan MT, Khan MA. Effects of Diluents on Physical and Chemical Stability of Phenytoin and Phenytoin Sodium. AAPS PharmSciTech 2020;21(3):114.

32. Ahalya R. Design and development of extended release dosage form of an anticonvulsant drug: PGP College of Pharmaceutical Science and Research Institute, Namakkal; 2013.

33. Madhavi N, Sudhakar B, Ravikanth P, Mohon K, Ramana Murthy K. Formulation and evaluation of Phenytoin sodium sustained release matrix tablet. J Bioequiv Availab 2012;4:12833.

34. Akhtar S, Dev P. Formulation and Evaluation of Chewable Multivitamin Tablet. Int J Curr Pharm Res 2017;9(4):61-4.

35. British Pharmacopoeia. HMSO Publication: London; 2007, Vol. 1, 664.

36. United States Pharmacopoeia (32)/National Formulary (27). Rockville, MD: The United States Pharmacopeial Convention; 2009. p. 786, 3294.

37. Saleem M, Shahin M, Srinivas B, Begum A. Evaluation of tablets by friability apparatus. Int J Res Pharm Chem 2014;4(4):837-40.

38. Lachman L, Liberman HA, Kanig LJ. Theory and Practice of Industrial Pharmacy. $3^{\text {rd }}$ ed. Dadar East (Mumbai): Vargese Publication House; 1986.p. 293-336.

39. Kimaro E, Tibalinda P, Shedafa R, Temu M, Kaale E. Formulation development of chewable albendazole tablets with improved dissolution rate. Heliyon 2019;5(12):e02911.

40. Kricka LJ, Park JY. Assay Principles in Clinical Pathology. In: McManus LM, Mitchell RN, editors. Pathobiology of Human Disease. San Diego: Academic Press; 2014. p. 3207-21.

41. Mulsa N, Sanghvi G, Purohit P, Sheth N, Vaishnav D. Development of the UV Spectrophotometric Method of Phenytoin Sodium in API and Stress Degradation Studies. Pharm Anal Qual Assur 2013;1:1-5.

42. Gupta A, Chidambaram N, Khan MA. An index for evaluating difficulty of Chewing Index for chewable tablets. Drug Dev Ind Pharm 2015;41(2):239-43.

43. Habib W, Alanizi A, Abdelhamid M, Alanazi F. Accuracy of Tablet Splitting: Comparison Study between Hand Splitting and Tablet Cutter. Saudi Pharm J 2013;22. 